\title{
CORRECTION
}

\section{Correction to: Inter- and intraspecific variability of morphometric parameters of rodent spermatozoa}

\author{
G. Yu. Smirnov ${ }^{1}$ M. V. Modorov ${ }^{1} \cdot$ Yu. A. Davydova ${ }^{1}$ (i)
}

Published online: 9 July 2021

(c) Springer-Verlag GmbH Germany, part of Springer Nature 2021

\section{Correction to: Zoomorphology}

https://doi.org/10.1007/s00435-021-00531-7

Authors would like to correct the error in the project numPublisher's Note Springer Nature remains neutral with regard to ber, in "acknowledgements" section, on page 11.

The original content is,

"This research was funded by RFBR (Russian Foundation for Basic Research), project no. 19-31-27001".

The corrected version is,

"This research was funded by RFBR (Russian Foundation for Basic Research), project number 19-34-90004".

The original article can be found online at https://doi.org/10.1007/ s00435-021-00531-7.

Yu. A. Davydova

davydova@ipae.uran.ru

1 Institute of Plant and Animal Ecology, Ural Branch,

Russian Academy of Sciences, 8th Marta St. 202,

Yekaterinburg 620144, Russia 